\title{
KONSEP MOTIVASI PEMBELAJARAN
}

\author{
Almaydza Pratama Abnisa \\ STAI Asy-Syukriyyah Tangerang \\ almaydzapratamaabnisa@gmail.com
}

\begin{abstract}
Learning motivation is one of the factors that can determine the learning outcomes of students. The existence of learning motivation can provide energy that drives all potential, raises high desire, and increases togetherness which will have an effect on arousing, directing and maintaining student behavior towards the learning environment. Thus the goal of achieving the expected material will be achieved. Therefore learning motivation plays an important role in learning because of several factors: First, learning motivation gives enthusiasm to students in learning activities. Second, learning motivation is a determinant of the kinds of activities that students want to carry out. Third, learning motivation provides instructions for students to behave.
\end{abstract}

Keyword: Motivation, Learning

\section{PENDAHULUAN}

Proses pembelajaran sangat terkait dengan motivasi peserta didik, keberadaan motivasi dalam proses pembelajaran sangat berperan penting dalam mempengaruhi semua aspek-aspek dalam pembelajaran. ${ }^{1}$ Peserta didik melaksanakan pembelajaran dengan memotivasi peserta didik akan melaksanakan kegiatan-kegiatan pembelajaran secara maksimal untuk mencapai tujuan pembelajaran, yaitu perubahan prilaku kognitif, afektif, psikomotorik, dan spritual. Sehingga motivasi menjadi sumber penentu peserta didik dalam memahami tujuan pembelajaran, ketika motivasinya kuat maka peserta didik akan meningkatkan intensitas dan segala perhatiannya untuk mencapai tujuan pembelajaran. ${ }^{2}$ Begitu juga dengan pendidik yang mempunyai motivasi dapat memaksimalkan peserta didiknya dalam pembelajaran, membuat perencanaan pembelajaran dan senantiasa bekerja bersama peserta didiknya dalam mencapai tujuan pembelajaran. ${ }^{3}$

Pendidik yang mempunyai motivasi akan senantiasa meningkatkan kualitas pembelajaran di kelas, seperti peningkatan pemahaman terhadap materi atau metode yang akan di terapkan dalam pembelajaran. Sehingga motivasi pendidik berperan penting dalam

\footnotetext{
${ }^{1}$ Henry Clay Lindgren, Educational Psychologyin The Classroom, Toronto: John Wiley and Sons, 1976, h. 29.

${ }^{2}$ Charles M. Reigeluth, Instructional Design Theories and Models, An Overview of Their Status, New York: Routledge, 1999, h. 23.

${ }^{3}$ Bruce Joyce dan Marsha Weil, Models of Teaching, New York: Allyn and Bacon Scuter, 2009, h. 6.
} 
pembelajaran bagi peserta didik. ${ }^{4}$ Ketika melaksanakan pembelajaran dengan semangat yang tinggi, tanpa diperintah peserta didik akan melaksanakan pembelajaran dengan maksimal, maka pendidik selalu menggambarkan bahwa inilah peserta didik yang baik. Hal tersebut dikarenakan, pendidik memberikan motvasi pembelajaran sehingga peserta didik mau melaksanakan pembelajaran. Pendidik harus memahami hal tersebut, maka pendidik akan mendalami bagaimana lingkungan peserta didik, dan peserta didik akan melaksanakan pembelajaran tanpa beban tetapi atas motivasi dari dalam dirinya sendiri. ${ }^{5}$ Gibson menegaskan dengan adanya motivasi peserta didik akan bersedia untuk menumbuhkan upaya yang tinggi ke arah tujuan yang akan dicapai, yang sesuaikan dengan pemahaman upaya tersebut dalam memberikan kebutuhan kepada peserta didik. ${ }^{6}$

Sehingga penulisan ini bertujuan dapat mempengaruhi peserta didik disaat ia akan memahami bahan yang baru atau pada saat ia melaksanakan pembelajaran dari karya dan prakarya, strategi, dan pelaksanaan pembelajaran yang sebelumnya dipelajari, dimana semua itu mempunyai peranan yang baik bagi pelaksanaan pembelajaran. ${ }^{7}$ Selanjutnya, motivasi dapat mempengaruhi kapan, apa, dan bagaimana peserta didik melaksanakan pembelajaran. Peserta didik yang mendapatkan motivasi pembelajaran ia akan meningkatkan intensitas terhadap kegiatan pembelajaran, serta menyampaikan perhatian yang tinggi terhadap apa yang diintruksikan pendidik, selalu melaksanakan evaluasi diri terhadap pemahaman bahanbahan yang akan dipahami, serta memiliki semangat yang besar agar dapat memahami tujuan pembelajaran. ${ }^{8}$

\section{KAJIAN TEORI}

Dalam prilaku pembelajaran peserta didik mempunyai mental penggerak yang sangat besar, seperti keinginan, perhatian, kemauan cita-cita yang disebut motivasi pembelajaran. Pola dasar moivasi tersebut adalah kebutuhan, dorongan, dan tujuan peserta didik. Motivasi pembelajaran berperan besar untuk di pahami oleh peserta didik maupun pendidik. Kendali motivasi pembelajaran ada di pundak para pendidik, karena pendidik berperan memperkuat motivasi pembelajaran pada usia wajib pembelajaran selama minimal sembilan tahun, dan berperan memperkuat motivasi pembelajaran sepanjang hayat.

\footnotetext{
${ }^{4}$ Ramaliyus, Psikologi Agama, Jakarta: Kalam Mulia, 2012, h. 102.

${ }^{5}$ Mardianto, Psikologi Pendidikan, Medan: Perdana Publishing, 2012, h. 192.

${ }^{6}$ Stephen P. Robbins, Organizational Behavioral: Concepts, Controversies, and Aplication, Englewood Clipffs: Prentice Hall International, 1989, h. 147.

${ }^{7}$ Esa Nur Wahyuni, Motivasi dalam Pembelajaran, Malang: UIN Malang Press, 2009, h. 38

${ }^{8}$ Pritrich dan Schunk, Motivational In Education: Theory, Research, and Aplications, Englewood Cliffs: Prentice Hall, 1996, h. 59.
} 
Perilaku pembelajaran yang mengandung motivasi yang di desain oleh pendidik dan di laksanakan oleh peserta didik, maksudnya pendidik adalah seorang yang berperan dalam menyusun prinsip-prinsip motivasi pembelajaran, dan dilaksanakan dalam proses pembelajaran peserta didik. Pendidik bertugas membimbing, memotivasi, menjadi teladan bagi peserta didiknya yang mempunyai motivasi yang sangat besar dalam pembelajaran.

Perilaku pembelajaran memiliki tiga ciri khusus diantaranya, Pertama, sikap yang dimotivasi secara terus-menerus, maksudnya peserta didik tetap ada untuk waktu jangka yang relatif lama. Kedua, sikap yang dimotivasi diarahkan ke arah pencapaian sesuatu tujuan. Ketiga, perilaku pembelajaran merupakan perilaku yang tumbuh disebabkan adanya kebutuhan yang dirasakan. ${ }^{9}$ Kekuatan yang memberi motivasi pembelajaran pada peserta didik, yaitu kekuatan yang membimbing ke arah persoalan atau bentuk sikap peserta didik, jumlahnyatak terhitung dan mengubah tingkatan yang luas, bukan saja dari satu individu ke individu lainnya, tetapi juga dari waktu ke waktu pada personil yang sama. Kekuaatan itu sering disebut dengan kebutuhan. ${ }^{10}$

Upaya pendidik untuk memotivasi pembelajaran peserta didik mencapai keberhaasilan, maka pendidik harus menciptakan prinsip-prinsip motivasi pembelajaran yang dirasakan di dalam peserta didik, atau pendidik menyediakan peralatan untuk memenuhi kebutuhan pada diri peserta didik. sehingga untuk memotivasi peserta didik, pendidik perlu memahami terkait kebutuhan fundamentalis peserta didik. ${ }^{11}$

\section{METODE PENELITIAN}

Penulis memakai metode tematik dengan pendekatan kualitatif, baik pada saat menganalisis permasalahan dari sudut pandang psikologis maupun ketika menggunakan sumber data. Metode ini di pilih karena dapat digunakan sebagai penggali konsep motivasi pembelajaran. Dan metode ini tidak didasarkan pada sampel statistik. ${ }^{12}$ Dalam pengumpulan data, penulis mengunakan teknik riset kepustakaan (library research). ${ }^{13}$ Data-data tertulis yang dipublikasikan berupa buku, jurnal, artikel, softwere, dan website relevan dengan penulisan ini. Pembahasan penulisan ini dilakukan dengan metode deskriptif yang menggambarkan, memaparkan, melaporkan secara fakta nyata suatu keadaan, suatu obyek

\footnotetext{
${ }^{9}$ Kompri, Motivasi Pembelajaran Perspektif Guru dan Siswa, Bandung: PT. Remaja Rosdakarya, 2015, h. 6.

${ }^{10}$ Rensis Likert, Motivasi dan Prilaku, Semarang: Dahara Prize, 1992, h. 9.

${ }^{11}$ Winardi, Manajemen Perilaku Organisasi, Jakarta: Kencana, 2004, h. 347.

${ }^{12}$ Koeswinanrno, Metode Kualitatif, Yogyakarta: UIN Sunan Kalijaga, 2006, h. 121.

${ }^{13}$ Riset kepustakaan merupakan penulisan yang memakai sumber-sumber kepustakaan dalam membahas permasalahan yang telah dirumuskan.
} 
atau suatu peristiwa yang terjadi, serta menyingkapkan fakta yang saling berhubungan antar permasalahan yang dibahas dalam penulisan dalam suatu bentuk susunan penulisan.

\section{PEMBAHASAN}

\section{Konsep Motivasi}

Menurut Morgan motivasi diartikan sebagai pendorong atau penggerak yang berasal dari dalam diri peserta didik untuk bertindak ke arah suatu tujuan tertentu. ${ }^{14}$ Ducan mengemukakan motivasi adalah dorongan yang muncul dari diri peserta didik untuk melakukan tugas secara keseluruhan berdasarkan tanggung jawab masing-masing. ${ }^{15}$ Motivasi merupakan kekuatan yang mendorong peserta didik melakukan sesuatu untuk mencapai tujuan, kekuatan-kekuatan tersebut pada dasarnya distimulus oleh berbagai macam kebutuhan, seperti: Pertama, keinginan yang hendak dipenuhinya. Kedua, tingkah laku. Ketiga, umpan balik. ${ }^{16}$ James L. Gibson dan kawan-kawan memberikan pandangannya bahwa motivasi adalah sebagai suatu konsep yang dapat digunakan ketika menggerakkan peserta didik untuk memulai dan berprilaku secara langsung sesuai dengan apa yang dikehendaki pendidik. ${ }^{17}$

Menurut Syaiful Bahri Djamarah motivasi adalah suatu perubahan energi di dalam pribadi peserta didik yang ditandai dengan timbulnya afektif atau perasaan dan reaksi untuk mencapai tujuan. ${ }^{18}$ Istilah motivasi berasal dari kata motif yang dapat diartikan sebagai kekuatan yang terdapat dalam diri peserta didik, yang menyebabkan peserta didik tersebut bertindak atau berbuat. ${ }^{19}$ Motif tidak dapat diamati secara langsung, tetapi dapat diinterpretasikan dalam tingkah lakunya, berupa rangsangan, dorongan, atau pembangkit tenaga tumbuhnya suatu perilaku tertentu. Motivasi asal kata dari aksara latin yaitu movere artinya bergerak. ${ }^{20}$ Soekijo Notoatmodjo, mengartikan motivasi adalah sesuatu dorongan di dalam diri seseorang yang membuat bertindak. ${ }^{21}$

\footnotetext{
${ }^{14}$ C.T. Morgan, R.A. King and Schopler, Introduction to Psychology, New York: McGraw Hill Book Company, 1986, h. 38.

${ }^{15}$ W. Jack Ducan, Organizational Behavior, Boston: Hounhton Mifflin Coy, 1981, h. 1.

${ }^{16}$ Don Hellriegel and John W. Slocum, Organizational Behavior, New York: Harper and Row Publisher, 1979, h. 390.

${ }^{17}$ James L. Gibson, John M. Ivancevich, James H. Donnelly, Organiversies, Texas: Business Publication, 1985, h. 100.

${ }^{18}$ Syaiful Bahri Djamarah, Psikologi Pendidikan, Jakarta: Rineka Cipta, 2011, h. 34.

${ }^{19}$ Isbandi Rukminto Adi, Psikologi, Pekerjaan Sosial, dan Ilmu Kesehjatraan Sosial: Dasar-Dasar Pemikiran, Jakarta: Grafindo Persada, 1994, h. 154.

${ }^{20}$ Hasibuan, Organisasi dan Motivasi, Jakarta, Bumi Aksara, 2010, h. 21.

${ }^{21}$ Soekijo Notoatmodjo, Pengembangan Sumber Daya Manusia, Jakarta: PT. Rineka Cipta, 2009, h. 114.
} 
Hal ini senada dengan pendapat Hamzah B. Uno menyatakan motivasi itu bisa membuat orang untuk melakukan kegiatan, sehingga dapat menyelesaikanya. ${ }^{22}$ Lain halnya dengan konsep motivasi Ranupandojo dan Husnan menjelaskan motivasi ialah suatu proses yang dapat mempengaruhi seseorang untuk menjalankan apa yang diinginkan. ${ }^{23}$ Menurut Husaini Usman motivasi itu alat bagi pendidik untuk mengarahkan peserta didik belajar dengan sungguh-sungguh sesuai dengan yang di cita-citakan. ${ }^{24}$ Juga Manullang ikut berpendapat bahwa motivasi adalah sebuah prilaku pendidik yang memberikan semangat, inspirasi dan dorongan kepada peserta didik. ${ }^{25}$ Djaali menambahkan motivasi adalah keadaan yang terdapat di dalam diri peserta didik yang mendorong untuk melakukan aktifitas untuk mencapai tujuan tertentu. ${ }^{26}$ Sehingga motivasi merupakan perilaku yang akan menentukan tujuan. ${ }^{27}$ W.S. Winnkel menegaskan motivasi merupakan dorongan yang terdapat dalam diri peserta didik untuk berusaha mengadakan perubahan tingkah laku yang lebih baik dalam memenuhi kebutuhannya. ${ }^{28}$

Menurut Mahmud motivasi ialah keadaan internal organisme manusia yang mendorongnya untuk berbuat sesuatu. ${ }^{29}$ Artinya motivasi sebagai peran utama untuk bertingkah laku secara terarah. M. Ngalim Purwanto mengemukakan baha motivasi ialah segala sesuatu yang mendorong peserta didik untuk bertindak melakukan sesuatu. ${ }^{30}$ Ahmad Thonthowi juga mengemukakan bahwa tindakan belajar yang bermotivasi dapat dikatakan sebagai tindakan belajar yang dilakukan oleh peserta didik yang didorong oleh kebutuhan yang dirasakannya, sehingga tindakan itu tertuju ke arah sesuatu tujuan yang diidamkan. ${ }^{31}$ Sedangkan menurut Sumadi Suryabrata motivasi adalah keadaan dalam diri peserta didik yang mendorong untuk melakukan aktivitas-aktivitas tertentu guna mencapai sesuatu tujuan. ${ }^{32}$ Mardianto menjelaskan motivasi adalah proses yang memberi semangat, arah, dan kegigihan perilaku, artinya perilaku yang termotivasi adalah perilaku yang peruh energi, terarah dan bertahan lama.

\footnotetext{
${ }^{22}$ Hamzah B. Uno, Teori Motivasi dan Pengukurannya, Jakarta: PT. Bumi Aksara, 2008, h. 92.

${ }^{23}$ Ranupandojo dan Husnan, Psikologi Motivasi, Yogyakarta: LKIS, 1990, h. 197.

${ }^{24}$ Husaini Usman, Belajar Teori, Praktik, dan Riset Pendidikan, Jakarta: PT. Bumi Aksara, 2011, h. 249.

${ }^{25}$ Manullang, Belajar Personalia, Yogyakarta: UGM Press, 2000, h. 12.

${ }^{26}$ Djaali, Psikologi Pendidikan, Jakarta: Bumi Aksara, 2007, h. 101.

${ }^{27}$ Yamin, Metode Pembelajaran yang Berhasil, Jakarta: Gaung Persada Press, 2003, h. 82.

${ }^{28}$ W.S. Winkel, Psikologi Pengajar, Jakarta: Grafindo, 1996, h. 151.

${ }^{29}$ Mahmud, Psikologi Pendidikan, Bandung: Pustaka Settia, 2010, h. 100

${ }^{30}$ M. Ngalim Purwanto, Psikologi Pendidikan, Bandung: PT. Remaja Rosdakarya, 1998, h. 60.

${ }^{31}$ Ahmad Thonthowi, Psikologi Pendidikan, Bandung: Angkasa, 1993, h. 68.

${ }^{32}$ Sumadi Suryabrata, Psikologi Pendidikan, Jakarta: Rajawali Pers, 2011, h. 70.
} 
Di samping itu, motivasi juga dinilai sebagai suatu daya dorong (driving force) yang menyebabkan peserta didik dapat berbuat sesuatu untuk mencapai tujuan. Dalam hal ini, motivasi menunjuk pada gejala yang melibatkan dorongan perbuatan terhadap tujuan tertentu. ${ }^{33}$ Merdianto memberikan tiga kata kunci dalam pengertian motivasi: Pertama, dalam motivasi terdapat dorongan yang menjadikan peserta didik mengambil tindakan atau sebaliknya. $^{34}$ Kedua, dalam motivasi terdapat satu pertimbangan apakah harus memprioritaskan tindakan alternatif, baik itu tindakan A atau tindakan B. Ketiga, dalam motivasi terdapat lingkungan yang memberi atau menjadikan sumber masukan atau pertimbangan peserta didik untuk melakukan tindakan pertama atau kedua. ${ }^{35}$

Mitchell menjelaskan motivasi adalah proses yang menjelaskan intensitas, arah dan ketekunan seorang peserta didik untuk mencapai tujuannya. ${ }^{36}$ Menurut Kompri motivasi dapat diartikan sebagai kekuatan energi seseorang yang dapat menimbulkan tingkat persistensi dan antusiasmenya dalam melaksanakan suatu kegiatan, baik yang bersumber dari dalam diri peserta didik itu sendiri, maupun dari luar diri peserta didik. ${ }^{37}$ Menurut A.A. Anwar Prabu Mangkunegara motivasi adalah energi untuk membangkitkan dorongan dalam diri peserta didik. ${ }^{38}$ Mulyasa mengemukakan motivasi adalah tenaga pendorong atau penarik yang mnyebabkan adanya tingkah laku ke arah tujuan tertentu. ${ }^{39}$

Dari pengertian pandangan para tokoh tersebut penulis berpandangan bahwa motivasi adalah suatu tenaga yang mendorong seseorang untuk bertindak melakukan kegiatan yang di harapkan. Dengan demikian, setiap peserta didik yang mempunyai motivasi akan sangat mempengaruhi kemauannya sehingga peserta didik akan didorong untuk berprilaku dan bertindak kepada tujuan. Oleh karena itu motivasi sangat berperan penting di dalam pembelajran untuk mencapai target yang di harapkan. Senada dengan penjelasan Siagian bahwa dalam pembelajaran aspek motivasi mutlak mendapat perhatian yang serius dari para pendidik. ${ }^{40}$ Printich dan Schunk mengartikan motivasi sebagai usaha menggerakkan, serta energi fisik yang memberikan kekuatan kepada peserta didik untuk melakukan tindakan

\footnotetext{
${ }^{33}$ Harold Koontz and Hainz Weihrich, Management Ninth Edition, New York: McGraw Hill Book Company, 1997, h. 411.

${ }^{34}$ Mardianto, Psikologi Pendidikan, Medan: Perdana Publishing, 2012, h. 186.

${ }^{35}$ Mardianto, Psikologi Pendidikan..., 2012, h. 186.

${ }^{36}$ Mitchell, Research in Organizational Behavior, Greenwich CT: JAI Press, 1997, h. 60.

${ }^{37}$ Kompri, Motivasi Pembelajaran Perspektif Guru dan Siswa, Bandung: PT. Remaja Rosdakarya, 2015, h. 3.

${ }^{38}$ A.A. Anwar Prabu Mangkunegara, Evaluasi Kinerja, Bandung: Refika Aditama, 2005, h. 93.

${ }^{39}$ Mulyasa, Menjadi Kepala Sekolah Profesional, Bandung: PT. Remaja Rosdakarya, 2005, 143.

${ }^{40}$ Sondang P. Siagian, Kiat Meningkatkan Produktivitas Belajar, Jakarta: PT. Rineka Cipta, 2002, h. 94.
} 
tertentu. ${ }^{41}$ Fudyartanto meyatakan motivasi sebagai sebuah fenomena yang melibatkan stimulation (perangsang) tindakan ke arah tujuan-tujuan tertentu di mana sebelumnya kecil bahkan tidak ada. ${ }^{42}$ Serta Atkinson mendifiniskan motivasi adalah sebuah istilah yang mengarahkan kepada adanya kecenderungan bertindak untuk menghasilkan satu atau lebih pengaruh-pengaruh. ${ }^{43}$

Dengan demikian motivasi penting bagi peserta didik karena motivasi ini bisa mempengaruhi, menyalurkan, menginspirasi dan mendukung aktifitas peserta didik supaya giat dalam pembelajaran dan antusias dalam menggapai hasil yang maksimal. ${ }^{44}$ Maka penulis berfikir bahwa motivasi sebagai pondasi dasar peserta didik di sekolah hingga berinteraksi di masyarakat baik bersifat politik, ekonomi, sosial dan bermacam-macam prilaku yang sangat kompleks. Dalam pembelajaran di sekolah motivasi menjadi sangat penting dalam rangka proses pembimbing, pengembangan, pembinaan serta sebagai pengarah tujuan peserta didik. Karena itu pendidik merupakan salah satu sumber daya manusia yang sangat menentukan arah peserta didik sesuai yang telah di rencanakan. Dimyati dan Mudjiono menjelaskan bahwa ada tiga komponen utama dalam motivasi yaitu: kebutuhan, dorongan, dan tujuan. ${ }^{45}$

Dalam hal ini kebutuhan terjadi apabila peserta didik merasa ada ketidakseimbangan antara apa yang ia miliki dan ia harapkan. Dorongan merupakan kekuatan mental untuk melakukan kegiatan dalam rangka memenuhi harapan dan pencapaian tujuan. Dorongan yang berorientasi pada tujuan tersebut merupakan inti dari motivasi. Tujuan adalah hal yang ingin dicapai oleh seorang peserta didik. Sehingga dengan motivasi yang tepat, para peserta didik akan terdorong untuk berbuat maksimal mungkin dalam melaksanakan pembelajaran karena meyakini bahwa dengan keberhasilan mencapai tujuan dan berbagai sasarannya, kepentingankepentingan pribadi para peserta didik tersebut terpelihara pula. ${ }^{46}$

Tujuan motivasi adalah sarana untuk mencapai suatu tujuan tertentu. ${ }^{47}$ Bagi pendidik motivasi bertujuan untuk menggerakkan, mendorong, memacu peserta didik agar muncul keinginan, kemauan untuk meningkatkan intensitas dalam pembelajaran sehingga tercapai tujuan pendidikan sesuai dengan yang diharapkan dan ditetapkan dalam kurikulum. ${ }^{48}$

\footnotetext{
${ }^{41}$ Printrich and Schunk, Motivation In Education: Theory, Research, and Aplications, Englewood Cliffs: Prentice Hall, 1996, h. 24.

${ }^{42}$ Fudyartanto, Psikologi Pendidikan, Yogyakarta: Global Pustaka Umum, 2002, h. 34.

${ }^{43}$ Atkinson, Pengantar Psikologi, Jakarta: Erlangga, 1997, h. 12.

${ }^{44}$ Hasibuan, Belajar Sumber Daya manusia, Jakarta: Bumi Aksara, 2000, h. 146.

${ }^{45}$ Dimyati dan Mudjiono, Belajar dan Pembelajaran, Jakarta: Rineka Cipta, 2010, h. 80

${ }^{46}$ Sondang P. Siagian, Manajemen Sumber Daya Manusia, Jakarta: Bumi Aksara, 1994, h. 285.

${ }^{47}$ Sutrisno dan Edy, Belajar Sumber Daya Manusia, Jakarta: Kencana Prenada Media, 2009, h. 124.

${ }^{48}$ Agus Sunyoto, Belajar Sumber Daya Manusia, Jakarta: IPWI, 1994, h. 34.
} 
Pernyataan ahli tersebut, dapat diartikan bahwa yang dimaksud tujuan adalah sesuatu yang berada diluar diri peserta didik sehingga kegiatan peserta didik lebih terarah karena akan berusaha lebih semangat dan giat dalam berbuat sesuatu. Maka motivasi akan lebih berhasil jika memiliki tujuan yang jelas dan dapat disadari oleh peserta didik. ${ }^{49}$ Serta seorang pendidik harus mengenal dan memahami latar belakang kehidupan, kebutuhan, prilaku individu peserta didik.

Nasution menjelaskan tujuan motivasi terbagi tiga bagian. Pertama, motivasi mendorong munculnya prilaku, tanpa adanya motivasi maka tidak akan ada perubahan. Kedua, motivasi bertujuan sebagai pengarah perbuatan untuk mencapai tujuan. Ketiga, motivasi bertujuan sebagai penggerak, yang akan menentukan lambat atau cepat peserta didik menyelesaikan kegiatan di saat pembelajaran. ${ }^{50}$

Maka penulis perpandangan tujuan motivasi ini menentukan tingkat keberhasilan atau gagalnya proses dalam pembelajaran di sekolah. Pembelajaran tanpa adanya motivasi akan sulit berhasil. Pendidik yang mengetahui tujuan dari motivasi sehingga dapat menyesuaikan dengan dorongan, minat, motif yang ada pada peserta didik, dan pendidik berusaha agar peserta didik mempunyai motivasi individu yang maksimal. Dengan demikian beberapa tujuan untuk meningkatkan motivasi peserta didik dengan lima prinsip diantaranya: Pertama, tujuannya harus lebih spesifik, sehingga membuat peserta didik mengerti apa yang dibutuhkan. Kedua, tujuannya harus berada diantara level kesulitan sedang hingga tinggi, sehingga tujuan yang lebih sulit akan membuat penampilan lebih baik daripada tujuan biasa. Ketiga, peserta didik harus menerima tujuan, artinya ia harus mau berusaha untuk mencapainya. Keempat, peserta didik harus menerima umpan balik tentang kemajuannya sehubungan dengan tujuannya. Sehingga dengan umpan balik akan membantu kemajuan peserta didik dengan mengidentifikasi bahwa usaha lebih diperlukan. Kelima, tujuan yang tersistem bisa lebih partisipatif untuk mencapai tujuan berpartisipasi dalam mencapai tujuan membantu peserta didik mengerti apa yang diharapkan dari pendidik.

Menurut Sardiman fungsi motivasi ada tiga yaitu: Pertama, mendorong peserta didik untuk bertindak, motivasi dalam hal ini merupakan penggerak sebelum melakukan aktifitas pembelajaran. Kedua, motivasi menentukan arah tindakan, yaitu tindakan ke arah cita-cita yang akan dicapai, sehingga motivasi dapat memberikan arah dan kegiatan yang harus dilaksanakan sesuai dengan rumusan perencanaan. Ketiga, menyeleksi tindakan, yaitu

\footnotetext{
${ }^{49}$ Wahosumidjo, Kepemimpinan dan Motivasi, Jakarta: Ghalia Indonesia, 1992, h. 177.

${ }^{50}$ Nasution, Dikdatif Asas-Asas Mengajar, Jakarta: Bumi Aksara, 2000, h. 76.
} 
menentukan perilaku yang harus dikerjakan sesuai dngan tujuan dengan meninggalkan perilaku yang tidak bermanfaat bagi tujuan tersebut. ${ }^{51}$

Fungsi motivasi menurut Yamin meliputi sebagai berikut: Pertama, mendorong timbulnya kelakuan atau suatu perbuatan, tanpa motivasi maka tidak akan timbul sesuatu perbuatan dalam pembelajaran. Kedua, motivasi berfungsi sebagai pengarah, artinya mengarahkan perbuatan pencapaian tujuan yang diinginkan. Ketiga, motivasi sebagai pengerak, besar dan kecilnya motivasi akan menenukan cepat atau lambatnya suatu pembelajaran. $^{52}$

Ahmad Rohani membagi tiga fungsi motivasi diantaranya: Pertama, memberi semangat dan mengaaktifkan peserta didik supaya tetap berminat dalam pembelajaran. Kedua, memusatkan perhatian peserta didik pada tugas-tugas tertentu yang berhubungan dengan pencapaian tujuan pembelajaran. Ketiga, membantu memenuhi kebutuhan akan hasil peserta didik dalam pembelajaran. ${ }^{53}$

M. Ngalim Purwanto menjelaskan bahwa motivasi terbagi empat fungsi diantaranya: Pertama, sebagai motor penggerak bagi peserta didik, ibarat bahan bakar pada kendaraan. Kedua, menentukan arah perbuatan yaitu perbuatan ke arah perwujudan tujuan dan cita-cita. Ketiga, mencegah penyelewengan dari jalan yang harus ditempuh untuk mencapai tujuan, dalam hal ini, makin jelas tujuan maka semakin jelas pula jalan yang harus ditempuh. Keempat, menyeleksi perbuatan diri, artinya menentukan perbuatan mana yang harus dilakukan, yang serasi guna mencapai tujuan dengan menyampaikan perbuatan yang tidak bermanfaat bagi yujuan itu. ${ }^{54}$

Fudyartanto menekankan ada tiga fungsi motivasi, antara lain: Pertama, motivasi mengarahkan dan mengatur tingkah laku peserta didik. motivasi sering diasosiasikan sebagai pembimbing, pengarah, dan berorientasi pada tujuan, sehingga tingkah laku yang termotivasi akan bergerak dalam suatu arah secara spesifik. Tingkah laku tersebut memiliki maksud, ketekunan, dan kegigihan. Kedua, motivasi sebagai penyeleksi tingkah laku. Dengan adanya motivasi, maka tingkah laku individu mempunyai arah kepada tujuan yang dipilih oleh peserta didik itu sendiri. Seperti contoh seorang peserta didik yang ingin lulus ujian, maka ia berkonsentrasi dengan menggunakan strategi-strategi yang terpilih untuk mencapai tujuan. Ketiga, motivasi memberikan energi dan menahan tingkahlaku. Motivasi sebagai alasan atau

\footnotetext{
${ }^{51}$ Sardiman, Interaksi dan Motivasi Belajar Mengajar, Jakarta: Grasindo Persada, 2001, h. 54.

${ }^{52}$ Yamin, Profesionalisasi Guru dan KBK, Jakarta: Gaung Persada Press, 2006, h. 158-159.

${ }^{53}$ Ahmad Rohani, Pengelolaan Pengajaran, Jakarta: Rineka Cipta, 2004, h. 11-12.

${ }^{54}$ M. Ngalim Purwanto, Psikologi Pendidikan, Bandung: PT. Remaja Rosdakarya, 1998, h. 71.
} 
predisposisi perbuatan, berarti menjadi tenaga pondorong dan peningkatan tenaga sehingga terjadilah perbuatan yang tampak pada organisme. Energi psikis yang tersedia pada diri peserta didik tergantung pada dasar kecilnya motivasi yang ia miliki, jika motivasi kuat atau besar, maka akan tersedia energi yang lebih besar. Sebaliknya, jika energi yang tersedia lemah (kecil), maka energi yang tersedia kecil. Semakin besar sebuah motif, maka akan semakin bertambah efisien sebuah tingkah laku. Motivasi juga berfungsi untuk mempertahankan, agar perbuatan (minat) dapat berlangsung terus lebih lama. ${ }^{55}$

Penulis berpandangan bahwa dengan mengetahui fungsi dari motivasi seorang pendidik harus mengenal dan memahami benar-benar latar belakang kehidupan, kebutuhan dan kepribadian peserta didiknya. Hasil pembelajaran akan menjadi optimal dengan adanya motivasi, karena motivasi senantiasa menentukan intensitas usaha pembelajaran peserta didik. Sehubungan dengan hal tersebut, Varia Winasih memberikan tiga fungsi motivasi, yaitu: Pertama, motivasi berfungsi sebagai pendorong peserta didik untuk bertindak, jadi sebagai penggerak yang melepaskan energi. Motivasi dalam hal ini merupakan motor penggerak dari setiap kegiatan yang akan dilaksanakan. Kedua, Motifasi berfungsi menentukan arah perbuatan, yaitu ke arah tujuan yang hendak dicapai. Dengan demikian motivasi dapat memberikan arah dan kegiatan yang harus dilaksanakan sesuai dengan rumusan tujuan. Ketiga, motivasi berfungsi sebagai penyeleksi perbuatan, yaitu menentukan perbuatan-perbuatan yang harus dilaksanakan yang serasi guna mencapai tujuan, dengan menyisihkan perbuatan-perbuatan yang tidak bermanfaat bagi tujuan tersebut. ${ }^{56}$ Motivasi berfungsi sebagai pendorong usaha dan pencapaian prestasi. Adanya motivasi yang baik dalam pembelajaran akan menunjukkan hasil yang baik. Demikian pula apabila peserta didik mengetahui rangkaian dari motivasi pembelajaran yang baik, dilakukan dengan baik pula maka ia akan mencapai prestasi yang gemilang. ${ }^{57}$

Penulis berpandangan tidak ada motivasi memberi alternatif yang tepat apabila sebaliknya, bahwa prestasi adalah menjadi motivasi pembelajaran bagi peserta didik. bila ini terjadi maka motivasi akan memberikan kepuasan sesaat dan bukan permanen. Penulis menyimpulkan bahwa ada empat fungsi motivasi diantaranya, Pertama: sebagai pedoman bagi penelitian-penelitian. Kedua, sebagai kerangka mengorganisasi informasi-informasi tertentu. Ketiga, menjelaskan secara kompleks terhadap peristiwa-peristiwa yang sederhana. Keempat, mengorganisasi kembali pengalaman-pengalaman yang penting.

\footnotetext{
${ }^{55}$ Fudyartanto, Psikologi Pendidikan, Yogyakarta: Global Pustaka Umum, 2000, h. 32.

${ }^{56}$ Varia Winasih, Psikologi Pendidikan, Medan: La Tansa Pers, 2009, h. 111.

${ }^{57}$ Mardianto, Psikologi Pendidikan, Medan: Perdana Publishing, 2012, h. 192
} 
Motivasi dapat dibagi mejadi dua jenis yaitu: Pertama, motivasi Intrinsik ialah timbul tidak memerlukan rangsangan dari luar karena telah ada dalam diri peserta didik sendiri. ${ }^{58}$ Peserta didik ketika memiliki motivasi intrinsik dalam pembelajaran maka ia akan bersungguh-sungguh untuk menguasai, memahami, dan dapat mengimplemantasikan ilmu pengetahuan itu bukan karena motif lain seperti ingin nilai yang tinggi, hadiah, dan pujian. ${ }^{59}$ Motivasi instrinsik ini muncul karena peserta didik merasa membutuhkan pemahaman ilmu dari apa yang dipelajarinya. Kedua, motivasi ekstrinsik yaitu dorongan yang timbul adanya rangsangan untuk melakukan tindakan yang berasal dari luar diri seseorang. Peserta didik termotivasi karena keinginan untuk mencapai tujuan di luar dari pembelajaran. Seperti keinginan untuk mendapatkan prestasi yang tinggi, kelulusan, ijasah, gelar, penghargaan dan lain-lain. ${ }^{60}$

Sumadi Suryabrata juga membedakan jenis motivasi menjadi dua, yakni: Pertama, motivasi intrinsik yaitu motivasi yang fungsinya karena adanya dorongan dari luar, seperti peserta didik melaksanakan pembelajarankarena diberitahu bahwa akan ada ujian, peserta didik membaca sesuatu karena diberi tahu bahwa hal itu harus dilakukannya. ${ }^{61}$ Kedua, motivasi intrinsik yaitu motivasi yang fungsinya tidak perlu didorong dan distimulus dari luar. Di dalam diri peserta didik sendiri telah ada dorongan itu. Seperti peserta didik yang gemar membaca tidak perlu ada yang mendorongnya pesertadidik tersebut mencari bukubuku untuk dipelajarinya, peserta didik yang semangat dan bertanggung jawab tidak akan menanti dorongan dari orang lain dengan kesadaran ia sudah melaksanakan pembelajaran dengan sebaik-baiknya. ${ }^{62}$

Penulis berpandangan motivasi instrinsik ini haruslah ada kesadaran dari dalam diri, maka kesadaran ini sangat penting dimiliki setiap peserta didik. Bila peserta didik telah memiliki motivasi intrinsik maka intensitas pembelajaran akan berkembang, selalu ingin maju dan haus akan ilmu pengetahuan. Sedangkan motivasi ekstrinsik walaupun kurang baik akan tetapi sangat berpengaruh dalam proses pendidikan supaya peserta didik lebih maksimal dalam pembelajaran.

M. Ngalim Purwanto menggolongkan motivasi menjadi tiga jenis, yakni: Pertama, kebutuhan-kebutuhan organis, yakni motivasi yang berhubungan dengan kebutuhankebutuhan bagian dalam dari tubuh. Kedua, motivasi darurat yakni motivasi yang timbul jika

\footnotetext{
${ }^{58}$ John W. Santrock, Life Span Development, Texas: Brown and Benchmark, 1977, h. 312

${ }^{59}$ John W. Santrock, Life Span Development..., h. 312

${ }^{60}$ Ismail Solihin, Pengantar Belajar, Jakarta: Erlangga, 2009, hal 152.

${ }^{61}$ Sumadi Suryabrata, Psikologi Pendidikan, Jakarta: Rajawali Pers, 2011, h. 72.

${ }^{62}$ Sumadi Suryabrata, Psikologi Pendidikan..., h. 73.
} 
situasi menuntut timbulnya tindakan kegiatan yang cepat dan kuat dari pendidik. Dalam hal tersebut motivasi timbul akibat adanya rangsangan dari luar. Ketiga, motivasi obyektif yaitu motivasi yang diarahkan kepada suatu objek atau tujuan tertentu di sekitar kita. Motivasi ini timbul karena adanya dorongan dari dalam diri peserta didik. ${ }^{63}$

Penulis menyimpulkan bahwa motivasi yang terkait dengan pemaknaan dan peranan kognisi lebih merupakan motivasi intrinsik, yaitu motivasi yang muncul dari dalam, seperti minat atau keingintahuan, sehingga peserta didik tidak lagi termotivasi oleh bentuk-bentuk insentif atau hukuman. Sedangkan motivasi ekstrinsik ialah motivasi yang disebabkan oleh keinginan untuk menerima ganjaran atau menghindari hukuman, motivasi yang terbentuk oleh faktor-faktor eksternal berupa ganjaran dan atau hukuman.

Dalam proses pembelajaran, pendidik dan peserta didik keduanya terlibat dalam motivasi pembelajaran untuk mencapai keberhasilan yang sesuai dengan tujuan yang diharapkan. Motivasi pembelajaran tidak hanya penting bagi pendidik sebagai motivator tetapi juga peserta didik penting sebagai subjek dan objek pembelajaran. ${ }^{64}$ Tugas pendidik ialah memotivasi pembelajaran peserta didik untuk tercapainya tujuan yang direncanakan, serta memperoleh tingkah laku yang diinginkan.

Elliot, Kratochwill, travers dan Cook berpendapat bahwa motivasi sangat penting terhadap pembelajaran melalui empat cara, yaitu: Pertama, motivasi meningkatkan energi peserta didik untuk melakukan aktivitas dengan sungguh-sungguh, intensif, dan memunculkan usaha yang keras. ${ }^{65}$ Kedua, motivasi memberi arah bagi individu untuk mencapai tujuan yang ditetapkan. Ini berarti motivasi dapat mempengaruhi pilihan-pilihan peserta didik dalam membuat dan menghasilkan apa yang membuat mereka rasakan sebagai bentuk kepuasan. Ketiga, motivasi meningkatkan keinginan dan kesungguhan dalam melakukan aktivitas tertentu, serta memengaruhi kemungkinan peserta didik akan memulai segala sesuatu berdasarkan tangungjawab terhadap diri sendiri, dan siap menghadapi kesulitan. Keempat, motivasi mempengaruhi strategi pembelajaran dan proses kognitif yang digunakan peserta didik, sehingga akan memberikan perhatian terhadap sesuatu, mempelajari dan mempraktikkannya, dan mencoba melaksanakan pembelajaran dengan penuh makna,

\footnotetext{
${ }^{63}$ M. Ngalim Purwanto, Psikologi Pendidikan, Bandung: PT. Remaja Rosdakarya, 1998, h. 64.

${ }^{64}$ Varia Winarsih, Psikologi Pendidikan, Medan: La Tansa Pers, 2009, h. 113.

${ }^{65}$ Elliot, Kratochwill, Travers dan Cook, Educational Pyschology, USA: McGraw Hill Book, 2000, h. 231.
} 
juga meningkatkan kemauan untuk mencari bantuan pada saat peserta didik menghadapi kesulitan. ${ }^{66}$

Kompri menjelaskan pentingnya motivasi bagi pendidik yaitu: Pertama, membangkitkan, meningkatkan, dan memelihara semangat peserta didik untuk melaksanakan pembelajaran sampai berhasil. Membangkitkan, meningkatkan peserta didik bila tidak bersemangat dan memelihara semangatnya yang telah kuat untuk mencapai tujuan pembelajaran. Kedua, mengetahui dan memahami keragaman motivasi dalam kelas, oleh karena itu pendidik harus mampu menggunakan strategi mengajar yang tepat. Ketiga, meningkatkan dan menyadarkan pendidik untuk memilih keragaman peran seperti sebagai penasihat, fasilitator, instruktur, teman diskusi, dan penyemangat. Keempat, memberi peluang pendidik melaksanakan peran pedagogis membuat peserta didik melaksanakan pembelajaran sampai berhasil. Tantangan profesionalnya justru terletak pada mengubah peserta didik yang tak berminat menjadi bersemangat dalam pelaksanaan pembelajaran. ${ }^{67}$

Penulis menyimpulkan bahwa pentingnya motivasi bagi peserta didik adalah sebagai berikut: Pertama: Menyadarkan kedudukan pada awal, proses dan hasil akhir pembelajaran. Kedua, mnginformasikan tentang kekuatan usaha pembelajaran, yang dibandingkan dengan teman sejawat, jika terbukti usaha pembelajaran peserta didik belum memadai, maka ia berusaha setekun temannya yang berhasil dalam pembelajaran. Ketiga, mengarahkan kegiatan pembelajaran, seperti peserta didik belum seius dalam pembelajaran, maka ia akanmengubah perilakunya. Keempat, membesarkan semangat dalam pembelajar. Kelima, menyadarkan tentang adanya perjalanan pembelajaran dan kemudian melaksanakan yang berkesinambungan. Peserta didik dilatih untuk menggunakan kekuatan sedemikian rupa sehingga dapat berhasil.

Penulis berpandangan bahwa dalam memahami motivasi peserta didik dapat dilihat dari beberapa indikator, diantaranya: Pertama, durasi kegiatan. Kedua, frekuensi kegiatan. Ketiga, persistensi pada kegiatan. Keempat, ketabahan, keuletan dan kemampuan dalam menghadapi rintangan dan kesulitan. Kelima, pengorbanan untuk mencapai tujuan. Keenam, tingkat aspirasi yang hendak dicapai dengan kegiatan yang dilakukan. Ketujuh, tingkatkualifikasi prestasi atau produk yang dicapai dari kegiatan yang dilakukan. Kedelapan, arah dan sikap terhadap sasaran kegiatan.

${ }^{66}$ Elliot, Kratochwill, Travers dan Cook, Educational Pyschology, USA: McGraw Hill Book, 2000, h. 231.

${ }^{67}$ Kompri, Motivasi Pembelajaran Perspektif Guru dan Siswa, Bandung: PT. Remaja Rosdakarya, 2015, h. 234. 
Wibowo mengemukakan bahwa sebagai indikator motivasi diantaranya: Pertama, engagement merupakan janji peserta didik untuk menunjukkan tingkat antusiasme, inisiatif, dan usaha meneruskan. ${ }^{68}$ Kedua, Komitmen merupakan suatu tingkatan dimana peserta didik mengikat dengan organisasi dan menunjukkan tindakan organizational citizenship. Ketiga, kepuasan merupakan refleksi pemenuhan kontrol psikologis dan memenuhi harapan di tempat pembelajaran. Keempat, turnover merupakan kehilangan peserta didik yang dihargai. ${ }^{69}$

\section{Konsep Pembelajaran}

Pembelajaran adalah proses interaksi antara stimulus berupa pikiran, perasaan, gerakan, dan respons. ${ }^{70}$ Aunurrahman menjelaskan pembelajaran adalah suatu ausaha sadar yang dilakukan peserta didik dalam perubahan tingkah laku baik melalui latihan, dan pengalaman yang menyangkut aspek-aspek kognitif, afektif dan psikomotorik untuk memperoleh tujuan tertentu. ${ }^{71}$ Menurut Muhibbin Syah pembelajaran adalah suatu adaptasi atau penyesuaiana tingkah laku yang berlangsung secara progresif. $^{72}$ Dalam UU No. 2 tahun 2003 tentang Sisdiknas Pasal 1 ayat 20, pembelajaran adalah poroses interaksi peserta didik dan sumber belajar pada suatu lingkungan belajar. Sukiman mendifinisikan pembelajaran adalah suatu usaha untuk membuat peserta didik belajar. ${ }^{73}$ Sedangkan menurut Trianto pembelajaran adalah suatu proses dimana lingkungan individu digunakan untuk menghasilkan respons dan tingkah laku dalam kondisi khusus. ${ }^{74}$ Serta menurut Gagne ialah instruction is aset of events that affect learners in such a way taht learning is facilitated. ${ }^{75}$ Senada dengan Sardiman bahwa pembelajaran adalah rangkaian kegiatan jiwa raga, psiko-fisik untuk menuju ke perkembangan pribadi manusia seutuhnya, yang berarti menyangkut unsur cipta, rasa dan karsa, ranah kognituf, afektif dan psikomotorik. ${ }^{76}$

Penulis mendifinisikan pembelajaran adalah usaha sadar dan terencana untuk mewujudkan suasana belajar dan proses pembelajaran agar peserta didik secara aktif mengembangkan potensi dirinya untuk memiliki kekuatan spritual keagamaan, pengendalian

\footnotetext{
${ }^{68}$ Wibowo, Perilaku dalam Organisasi, Jakarta: Rajawali Pers, 2013, h. 110.

${ }^{69}$ Wibowo, Perilaku dalam Organisasi..., h. 110.

${ }^{70}$ Noel Entwistle, Styles of Learning and Teaching: An Integrated Outline of Educational Psychology for Students, Teachers, and Lecturers, New York: John Wiley and Sons, 1981, h. 216.

${ }^{71}$ Aunurrahman, Belajar dan Pembelajaran, Bandung: Alfabeta, 2008, h. 35.

${ }^{72}$ Muhibbin Syah, Psikologi Pendidikan Suatu Pendekatan Baru, Bandung: PT. Remaja Rosdakarya, 1999, h. 89.

${ }^{73}$ Sukiman, Pengembangan Media Pembelajaran, Jogjakarta: Pedagogia, 2012, h. 30.

${ }^{74}$ Trianto, Mendesain Model Pembelajaran Inovatif-Progresif, Jakarta: Kencana, 2009, h. 85.

${ }^{75}$ Gagne, Learning Hierarchies, New Jersey: Prentica Hall, 1971, h. 36.

${ }^{76}$ Sardiman AM, Interaksi dan Motivasi Belajar Mengajar, Jakarta: Raja Grafindo Persada, 2014, h. 21.
} 
diri, kepribadian, kecerdasan, akhlakul karimah, serta karakter ketrampilan yang bermanfaat bagi diri individu, keluarga, masyarakat, bangsa dan negara. Secara sederhana pembelajaran sebagai usaha untuk mempengaruhi emosi, intelektual, dan spritual peserta didik agar melaksanakan pembelajaran sesuai dengan keinginanya. Serta senada dengan Abudin Nata bahwa dengan adanya aktivitas pembelajaran akan terjadinya proses pengembangan prilaku keagamaan, aktivitas dan kreatifitas peserta didik melalui interaksi, komunikasi dan pengalaman. ${ }^{77}$ Maka pembelajaran berbeda dengan pengajaran, prinsipnya pengajaran menggambarkan aktivitas pendidik, dan pembelajaran menggambarkan aktivitas peserta didik. Evelin Siregar menegaskan konsep pembelajaran adalah kegiatan-kegiatan yang orientasinya kepada peserta didik agar terjadi pemblajaran dalam dirinya. ${ }^{78}$

Dengan demikian penulis berpandangan bahwa pembelajaran merupakan kunci setiap individu untuk mendapatkan ilmu pengetahuan. Dengan pembelajaran ilmu akan diserap dengan baik dengan metode pendekatan yang sesuai dengan tahapan pertumbuhan individu. Pembelajaran sangat berkaitan dengan tujuan hidup peserta didik, dan tujuan itu berbedabeda antara satu dengan yang lainnya. ${ }^{79}$ Maka pembelajaran seharusnya dilaksanakan dengan perencanaan yang sistematis. Selanjutnya di dalam pembelajaran ada usaha proses membimbing peserta didik, ada proses dua arah yaitu mengajar yang dilakukan kepada pendidik, sedangkan belajar dilakukan oleh peserta didik.

Oleh sebab itu pembelajaran sebagai proses belajar yang di rancang oleh pendidik untuk menciptakan kreativitas peserta didik yang dapat meningkatkan keahlian dalam berfikir, serta dapat meningkatkan penguasaan yang baik terhadap materi pembelajaran. Proses pembelajaran yang merupaka inti dari proses pendidikan formal di sekolah di dalamnya terjadi interaksi antara berbagai komponen pembelajaran. Komponen-komponen itu dapat dikelompokkan ke dalam tiga katagori, yaitu guru, isi atau materi pembelajaran, dan peserta didik. Interaksi antara ketiga komponen utama melibatkan sarana dan prasarana, seperti metode, media, dan penataaan lingkungan tempat pelaksanaan pembelajaran, sehingga akan tercipta situasi pembelajaran yang memungkinkan tercapainya tujuan yang telah direncanakan sebelumnya.

Penulis berpandangan bahwa pembelajaran harus diselenggarakan secara interaktif, inspiratif, menyenangkan, menantang, memotivasi peserta didik untuk berpartisipasi aktif,

\footnotetext{
${ }^{77}$ Abuddin Nata, Perspektif Islam Tentang Strategi Pembelajaran, Jakarta: Kencana, 2009, h. 85.

${ }^{78}$ Evelin Siregar, Teori Belajar dan Pembelajaran, Bogor: Ghalia Indonesia, 2010, h. 14.

${ }^{79}$ Ratna Wilis, Teori Belajar dan Pembelajaran, Jakarta: Erlangga, 2006, h. 98.
} 
serta memberikan ruang yang cukup bagi prakarsa, kreativitas, dan kemandirian sesuai dengan bakat, minat dan perkembangan fisik dan psikologis peserta didik.

Tujuan pembelajaran memiliki fungsi yang sangat penting dalam sistem pembelajaran, tujuan pembelajaran seperti jantung dalam sistem tubuh manusia sehingga dapat diartikan bahwa akan terjadi proses pembelajaran jikalau terdapat tujuan yang harus dicapai. Dengan demikian, sebagai kegiatan pembelajaran yang bertujuan, maka segala sesuatu yang dilakukan pendidik dan peserta didik dala proses pembelajaran hendaknya diarahkan untuk mencapai tujuan yang telah ditentukan. Maka dapat didifinisikan tujuan adalah pengikat segala aktivitas pendidik dan peserta didik, oleh sebab itu merumuskan tujuan pembelajaran merupakan langkah pertama yang harus dilakukan dalam merancang sebuah perencanaan program pembelajaran. ${ }^{80}$

Penulis berpandangan bahwa dalam usaha pencapaian tujuan pembelajaran perlu diciptakan adanya lingkungan kondisi pembelajaran yang lebih kondusif. Dengan kata lain, untuk mencapai tujuan pembelajaran tertentu harus diciptakan sistem lingkungan pembelajaran tertentu pula. Seperti tujuan untuk pengembangan nilai afeksi memerlukan penciptaan sistem lingkungan yang berbeda dengan sistem yang dibutuhkan untuk tujuan pembelajaran pengembangan gerak motorik, dan begitu seterusnya. Sardiman menegaskan tujuan pembelajaran secara umum terbagi tiga diantaranya: Pertama, tujuan pembelajaran adalah untuk mendapatkan pengetahuan. Kedua, tujuan pembelajaran adalah sebagai penanaman konsep dan ketrampilan. Ketiga, tujuan pembelajaran adalah untuk pembentukan sikap. ${ }^{81}$

\section{Konsep Motivasi Pembelajaran}

Menurut Hamzah B. Uno motivasi pembelajaran merupakan salah satu faktor yang turut menentukan hasil peserta didik. ${ }^{82}$ Hal yang sama dinyatakan Ismail Solihin bahwa motivasi pembelajaran sebagai kondisi yang berpengaruh membangkitkan, mengarahkan dan memelihara prilaku yang berhubungan dengan lingkungan pembelajaran. ${ }^{83}$ Motivasi pembelajaran dapat memberikan energi yang menggerakkan segala potensi yang ada, menciptakan keinginan yang tinggi dan luhur, serta meningkatkan kebersamaan yang berpengaruh membangkitkan, mengarahkan dan memelihara perilaku yang berhubungan

\footnotetext{
${ }^{80}$ Wina Sanjaya, Perencanaan dan Desain Sistem Pembelajaran, Jakarta: Kencana Prenada Media Group, 2008, h. 121.

${ }^{81}$ Sardiman A.M, Interaksi dan Motivasi Belajar Mengajar, Jakarta: PT. Raja Grafindo Persada, 2014, h. 27-28.

${ }^{82}$ Hamzah B. Uno, Teori Motivasi dan Pengukurannya..., h. 71.

${ }^{83}$ Ismail Solihin, Pengantar Belajar, Jakarta: Erlangga, 2009, h. 152.
} 
dengan lingkungan pembelajaran. ${ }^{84}$ Sedangkan menurut Winardi motivasi pembelajaran penting karena mendorong peserta didik untuk belajar dan bertindak, tanpa motivasi peserta didik tidak akan bertindak, bergerak dan belajar untuk kepentingan dirinya. ${ }^{85}$

Ambar Teguh Sulistyani menjelaskan motivasi pembelajaran merupakan proses pemberian dorongan pendidik kepada peserta didik supaya dapat melaksanakan pembelajaran dengan batasan yang diberikan untuk mencapai tujuan pembelajaran secara optimal, serta proses motivasi pembelajaran tersebut adalah serangkaian aktifitas yang harus dilalui untuk menumbuhkan dorongan peserta didik untuk melaksanakan pembelajaran. ${ }^{86}$ Menurut Oemar Hamalik motivasi pembelajaran sangat menentukan tingkat keberhsialan dan gagalnya pembelajaran peserta didik, pembelajaran tanpa adanya motivasi kiranya akan sangat sulit berhasil, sebab seorang peserta didik tidak mempunya motivasi dalam pembelajaran dan tidak akan mungkin melakukan aktivitas pembelajaran. ${ }^{87}$

Penulis mendifinisikan motivasi pembelajaran merupakan dorongan dari dalam dan dari luar diri peserta didik untuk bergerak, melaksanakan pembelajaran dengan maksimal supaya mendapatkan hasil yang di cita-citakan. Semakin besar motivasi pembelajaran peserta didik maka semakin besar pula keberhasilan yang dicapai. Dengan demikian sikap positif peserta didik terhadap situasi pembelajaran akan memperkuat untuk mencapai keberhasilan. Serta motivasi pembelajaran sebagai respon peserta didik terhadap usaha yang timbul dari dalam diri agar tumbuh dorongan untuk bertindak dan tujuan yang dikehendaki peserta didik tercapai. Motivasi pembelajaran tumbuh dari pengaruh timbal balik antara faktor individu dan lingkungan belajar. ${ }^{88}$ Kedudukan motivasi pembelajaran tidak hanya memberikan arah kegiatan belajar secara benar, lebih dari itu dengan motivasi pembelajaran peserta didik akan mendapat pertimbangan-pertimbangan positif. $^{89}$

\section{KESIMPULAN}

Penulis menyimpulkan motivasi pembelajaran sangat besar pengaruhnya dalam mencapai tujuan pembelajaran. Dengan demikian akan tercapainya kebutuhan akan prestasi,

\footnotetext{
${ }^{84}$ Amirullah dan Hanafi, Pengantar Belajar, Yogyakarta: Graha Ilmu, 2002, h. 146.

${ }^{85}$ Winardi, Motivasi dan Permotivasian Dalam Belajar, Jakarta: PT. Raja Grafindo Persada, 2002, h. 6.

${ }^{86}$ Ambar Teguh Sulistiyani, Memahami Good Governance dalam Perspektif Sumber Daya manusia, Yogyakarta: Gava Media, 2011, h. 76.

${ }^{87}$ Oemar Hamalik, Proses Belajar Mengajar, Jakarta: Bumi Aksara, 2013, h. 161.

${ }^{88}$ Wirawan, Kepemimpinan, Teori, Psikologi, Perilaku Sekolah, Aplikasi dan Penelitian, Jakarta: Raja Grafindo Persada, 2013, h. 678.

${ }^{89}$ Merdianto, Psikologi Pendidikan, Medan: Perdana Publishing, 2012, h. 113.
} 
afisiasi dan kekuatan yang diharapkan, sehingga dapat memotivasi dan menggerakkan semua potensi yang dimiliki peserta didik. Sehingga motivasi pembelajaran merupakan hal yang sangat berpengaruh dalam pembelajaran dikarnakan: Pertama, motivasi pembelajaran memberikan semangat peserta didik dalam Kegiatan-kegiatan pembelajaran. Kedua, motivasi pembelajaran sebagai pemilih dari tipe kegiatan dimana peserta didik berkeinginan untuk melaksanakannya. Ketiga, motivasi pembelajaran memberikan petunjuk pada tingkah laku.

\section{DAFTAR PUSTAKA}

Adi, Isbandi Rukminto. 1994. Psikologi, Pekerjaan Sosial, dan Ilmu Kesehjatraan Sosial: Dasar-Dasar Pemikiran, Jakarta: Grafindo Persada.

Amirullah dan Hanafi. 2002. Pengantar Belajar, Yogyakarta: Graha Ilmu.

Atkinson. 1997. Pengantar Psikologi, Jakarta: Erlangga.

Gibson, James L. John M. Ivancevich, James H. Donnelly, 1985. Organiversies, Texas: Business Publication.

Hamalik, Oemar. 2013. Proses Belajar Mengajar, Jakarta: Bumi Aksara.

Nasution. 2000. Dikdatif Asas-Asas Mengajar, Jakarta: Bumi Aksara.

Sanjaya, Wina. 2008. Perencanaan dan Desain Sistem Pembelajaran, Jakarta: Kencana Prenada Media Group.

Santrock, John W. 1977. Life Span Development, Texas: Brown and Benchmark.

Sardiman A.M. 2014. Interaksi dan Motivasi Belajar Mengajar, Jakarta: PT. Raja Grafindo Persada.

Siagian, Sondang P. 2002. Kiat Meningkatkan Produktivitas Belajar, Jakarta: PT. Rineka Cipta.

Siregar, Evelin. 2010. Teori Belajar dan Pembelajaran, Bogor: Ghalia Indonesia.

Solihin, Ismail. 2009. Pengantar Belajar, Jakarta: Erlangga.

Sukiman. 2012. Pengembangan Media Pembelajaran, Jogjakarta: Pedagogia.

Sulistiyani, Ambar Teguh, 2011. Memahami Good Governance dalam Perspektif Sumber Daya manusia, Yogyakarta: Gava Media.

Sunyoto, Agus. 1994. Belajar Sumber Daya Manusia, Jakarta: IPWI.

Suryabrata, Sumadi. 2011. Psikologi Pendidikan, Jakarta: Rajawali Pers.

Usman, Husaini. 2011. Belajar Teori, Praktik, dan Riset Pendidikan, Jakarta: PT. Bumi Aksara. 
Wahosumidjo. 1992. Kepemimpinan dan Motivasi, Jakarta: Ghalia Indonesia.

Wirawan. 2013. Kepemimpinan, Teori, Psikologi, Perilaku Sekolah, Aplikasi dan Penelitian, Jakarta: Raja Grafindo Persada.

Yamin. 2003. Metode Pembelajaran yang Berhasil, Jakarta: Gaung Persada Press.

Yamin. 2006 Profesionalisasi Guru dan KBK, Jakarta: Gaung Persada Press. 